\title{
HALING FOREIGN SUBSIDIARY CORPORATIONS INTO COURT UNDER THE 1934 ACT: JURISDICTIONAL BASES AND FORUM NON CONVENIENS
}

\author{
GLENN R. Sarno*
}

\section{INTRODUCTION}

In the wake of revolutionary political and economic developments on the international stage, ${ }^{1}$ increasing numbers of foreign issuers and investors seek to tap U.S. securities markets. ${ }^{2}$ As this trend continues, more plaintiffs will no doubt seek redress against foreign non-resident defendants for violations of U.S. securities laws. ${ }^{3}$ As threshold issues in such cases, courts will need to consider whether due process allows them to exercise personal jurisdiction over such foreign entities in light of the jurisdictional provisions of the Securities Exchange Act of $1934,{ }^{4}$ and whether to dismiss such cases for forum non conveniens.

\section{Copyright (C) 1992 by Law and Contemporary Problems}

* B.A. summa cum laude, University of Connecticut; J.D. with honors, Duke University; Judicial Clerk to Justice Robert L. Clifford, N.J. Supreme Court.

Special thanks to John R. and Annabelle Sarno.

1. Such developments include the death of the Soviet Union, German reunification, the reshaping of Eastern Europe, the promise of a Middle Eastern peace, the growing Westernization of Asia, the formation of the European Economic Community, and the continued globalization of national markets and economies.

2. See James D. Cox, Securities Regulation 12-13 (Little Brown, 1991).

3. Investors whose deals go awry due to a poor economic climate may have greater impetus to try to recover losses in actions alleging securities law violations.

4. The Act states:

The district courts of the United States . . . shall have exclusive jurisdiction of violations of this chapter or the rules and regulations thereunder .... Any suit or action may . . . be brought in any such district or in the district wherein the defendant is found or is an inhabitant or transacts business, and process in such cases may be served in any other district of which the defendant is an inhabitant or wherever the defendant may be found. Securities Exchange Act of 193415 USCA § 78aa (West Supp 1992) ("Exchange Act); see Leasco Data Processing Equipment Corp. v Maxwell, 468 F2d 1326, 1339-40 (2d Cir 1972) ("[U]se of the word 'wherever,' rather than 'where' or 'in which,' demonstrates an intention to authorize service on a defendant who can be 'found' only in a foreign country, and although the section does not deal specifically with in personam jurisdiction, it is reasonable to infer that Congress meant to assert personal jurisdiction over foreigners not present in the United States but, of course, not beyond the bounds of the due process clause of the Fifth Amendment.") (citations omitted).

Congress has not enacted a general federal long-arm statute. Omni Cap. Int'l v Rudolf Wolff Co., 484 US 97, 106 (1987). FRCP 4(e) and 4(f) authorize federal courts to use the service provisions in 
This article will examine the general theories and legal standards for obtaining personal jurisdiction over a nonresident foreign entity under section 27 of the 1934 Act. By way of example, the article will focus primarily on the theories of obtaining jurisdiction over a foreign subsidiary corporation that has a parent present in the United States for jurisdictional purposes. ${ }^{5}$ The foreign subsidiary model is valuable for two reasons. First, the jurisdictional analysis in such situations often implicates a full panoply of jurisdictional theories. Second, because U.S. companies frequently take advantage of opportunities abroad by forming foreign subsidiary corporations that, in turn, conduct international transactions, those subsidiaries increasingly risk being haled into U.S. courts for securities-law violations.

Part II will consider some salient legal and economic reasons for forming a foreign subsidiary corporation and will demonstrate how understanding the dynamics of a particular corporate group can yield better jurisdictional arguments. Part III will examine the major jurisdictional theories and legal standards. Finally, Part IV will discuss the roles played by the "reasonableness" prong of personal-jurisdiction analysis and the doctrine of forum non conveniens as safety valves for the improper or overbroad exercise of personal jurisdiction.

Ultimately, by using the information in this article, counsel can better predict when its foreign-subsidiary client will be haled into federal court for a securities-law violation, and can better craft a motion to dismiss and supporting affidavits ${ }^{6}$ for lack of in personam jurisdiction and/or forum non conveniens.

the relevant federal statute (see, for example, $\S 27$ ) or to borrow a state long-arm statute. Because $\S 27$ extends personal jurisdiction to the limits of due process, discussion of state long-arm statutes that can reach no farther is unnecessary.

5. The jurisdictional analysis should essentially be the same regardless of whether jurisdiction is sought over the foreign subsidiary or, in the more common scenario, whether jurisdiction is sought over the foreign parent of a domestic subsidiary. Phillip I. Blumberg, The Law of Corporate Groups: Procedural Problems in the Law of Parent and Subsidiary Corporations $\$ 3.09$ at 77 (Little Brown, 1983); Restatement (Second) of Conflict of Laws $\$ 52$, comment b (1971); see Gary B. Born \& David Westin, International Civil Litigation in United States Courts $111 \mathrm{n} 7$ (Kluwer, 1988) ("International Civil Litigation") (citing numerous cases). Logically, the same analysis applies when the parent and foreign subsidiary are both located outside the United States but the parent is otherwise present in the United States.

This article will focus primarily on the law as it has developed and is applied in federal courts sitting in New York. Although the primary focus of the paper is on litigation under the federal securities laws, some generic concepts of personal jurisdiction and forum non conveniens applicable to this area are illustrated with non-securities cases.

6. Such motions are made pursuant to FRCP 12(b). A 12(b) motion is usually accompanied by uncontroverted affidavits containing jurisdictional facts provided by potential witnesses. Although the specific contents of such affidavits vary, the types of facts used in them can be divined from a close reading of the case law. See, for example, Leema Enterprises, Inc. v Wills, 575 F Supp 1533, 1536 (SD NY 1983) (quoting a significant portion of defendant's affidavit). 


\section{Expanding Corporate EnTERPRises in a Shrinking World}

Large publicly held corporations in the United States are increasingly conducting business through foreign subsidiaries incorporated and operating under their own charters. ${ }^{7}$ Seeking to maximize the profitability of the entire operation, the parent corporation develops broad goals and policies in a centralized power base and then directs its foreign subsidiaries to implement those goals and policies. ${ }^{8}$ Generally, the decision to form a foreign subsidiary has its genesis in a combination of sound financial, managerial, and legal judgments. ${ }^{9}$ Sometimes, however, the decision is a matter of temporary expediency, transaction facilitation, or sentiment. ${ }^{10}$

Viewed from a legal standpoint, the foreign subsidiary functions to limit the litigation exposure of the entire corporate group, and allows both the subsidiary and parent corporation to predict with reasonable certainty into which jurisdictions they can be haled. ${ }^{11}$ For example, in securities litigation, a plaintiff seeking personal jurisdiction over a foreign subsidiary must

7. As of 1981, data from 100 of Fortune's largest 1000 American industrial companies, plus the 10 largest U.S. retailing companies, plus the 10 largest U.S. service companies, showed that the 117 corporations for which information was available had a total of 3,327 foreign subsidiaries; or, viewed differently, each corporation owned, on average, 28 subsidiaries. Blumberg. The Law of Corporate Groups $\$ 2.02 .1$ at 28 (cited in note 5). Another study, of 180 major U.S.-based multinational enterprises, found that as of January 1,1976 , they had a total of 11,198 foreign subsidiaries. Joan $P$. Curhan, William H. Davidson \& Rajan Suri, Tracing the Multinationals: A Sourcebook on U.S.-based Enterprises 210-11 (Ballinger, 1977).

8. See Raymond Vernon, Storm over the Multinationals: The Real Issues 28-29 (Harvard U Press, 1977). The economic strength of a corporation structured with foreign subsidiaries is that it can take advantage of different wages, tariffs, taxes, transportation costs, labor relations policies, and political philosophies in its daily decisions. Furthermore, the parent corporation can coordinate pricing, tax minimization, research and development, and the flow of corporate funds and assets on a global scale. Richard J. Barnet \& Ronald E. Müller, Global Reach: The Power of the Multinational Corporations 40-42 (Simon \& Schuster, 1974).

9. The following are some generic nonlegal considerations favoring the formation of a subsidiary: (1) Becoming the leaders of their own corporation, instead of being simple cogs within the larger machinery of the parent corporation, develops higher morale among the officers and management of the new subsidiary; (2) Forming a subsidiary can settle shareholder disputes or management unhappiness with the existing centralized corporate structure; (3) Employees, management, and officers in a subsidiary may work harder to compete in the marketplace and maximize profits for their own corporation than they would have as division managers; and (4) A parent corporation can earn profits from a product or service with which it does not want to associate itself by forming a subsidiary.

Some common legal considerations include the following: (1) limited liability of the parent for the acts of the subsidiary; (2) the ability of a subsidiary to engage in an activity prohibited under the parent's charter or by the national laws of the parent; and (3) tax benefits. Apart from those advantages, the parent must weigh the possibility that the subsidiary may develop interests that are adverse to the parent's, and may not readily follow the parent's broad policies and instruction, and furthermore that the subsidiary's officers and management may develop fiduciary duties to their own corporation that are adverse to their fiduciary duties to the parent corporation. For a discussion of the above, see Chester Rohrlich, Organizing Corporatc and Other Business Enterprises $\$ 10.02$ at 10-2 (Berden, 5th ed 1975).

10. Subsidiaries are commonly used to facilitate mergers and acquisitions requiring quick shareholder approval and/or insulation of the parent from certain liabilities. Also, establishing subsidiaries in large international cities, such as London, Tokyo, or New York, can simply serve as a "window dressing" and make a more impressive letterhead.

11. The following elaborates on this proposition: 
demonstrate that the subsidiary has sufficient "minimum contacts" with the United States to make jurisdiction fair and reasonable. ${ }^{12}$ As will be discussed in Part III, a common method of establishing a subsidiary's presence in the United States is to show that the parent, already present in the United States, disregards the separate corporate existence of the subsidiary such that the subsidiary is the parent's alter-ego. ${ }^{13}$ If alter-ego is proved, the subsidiary would be subject to suit in all fora in which jurisdiction over the parent is proper.

Determining which theory of organization will yield the best results depends on the specific character and dynamics of the parent/subsidiary relationship. For example, as a foreign subsidiary matures, it may exercise a great deal of autonomy in its operations. ${ }^{14}$ Likewise, business associations modeled on the investment company, conglomerate, or weakly integrated group structures may, by design, enjoy significant autonomy. ${ }^{15}$ The more autonomy a foreign subsidiary has over its operations, the more difficult the proof that it is the alter-ego of the domestic parent. ${ }^{16}$ Conversely, when a

[T]he subsidiary is more than a device to limit liability; it is an extraordinarily powerful conflicts device in the law of international business organizations. Indeed, this aspect of the subsidiary is independent of its risk shifting function.

The subsidiary structure operates as a conflicts device by minimizing the number of forums in which suit may be brought. A unitary firm that has 'minimum contacts' with several forums is usually subject to jurisdiction in each of these forums. A firm may, however, conduct activities in one of these jurisdictions through a subsidiary. If a suit against the firm arises from the subsidiary's activities, the firm is only subject to suit in this one jurisdiction, despite activities in other forums. The subsidiary thus serves a purpose similar to the one served by the forum non conveniens doctrine but yields far more predictable results.

Joseph H. Sommer, The Subsidiary: Doctrine without a Cause?, 59 Fordham L Rev 227-28 (1990) (footnotes omitted).

12. International Shoe Co. $v$ Washington, 326 US 310, 316 (1945) (defendant's liberty interest in not being subject to judgments of a forum with which the defendant has established no meaningful "contacts, ties, or relations," is rooted in the Due Process clause). Id at 319.

13. See Born \& Westin, International Civil Litigation at 104-05 (cited in note 5) for a general discussion of the alter-ego doctrine.

14. As the multinational enterprise grows and matures, the autonomy of each subsidiary changes. Pressures of local politics, the growth in scale of the total operation and the inevitable decentralization that follows, the size of the foreign subsidiary's operation, economic pressures on the corporate group as a whole, and the simple fact that as time goes by the local subsidiary may adopt its own corporate culture and staff its high management positions with locals, are all forces that make the foreign subsidiary more autonomous. See Alfred D. Chandler, Jr., The Visible Hand-The Managerial Revolution in American Business 463 (Belknap Press, 1977); Mira Wilkins, The Maturing of Multinational Enterprise: American Business Abroad from 1914 to 1970, at 436 (Harvard U Press, 1974); Peter J. Buckley \& Mark Casson, The Future of the Multinational Enterprise 105 (Holmes \& Meier, 1976); Blumberg, The Law of Corporate Groups $\$ 2.05 .2$ at 35 (cited in note 5).

15. According to Blumberg, there exist at least four common forms of corporate affiliations: (1) the "investment company," in which the parent is completely removed from the operations of the subsidiary; (2) the "conglomerate" in which the subsidiaries largely conduct their businesses separately, and in which the parent is generally in a different business than some of its subsidiaries; (3) the "strongly integrated group," in which parent and subsidiary are closely interrelated and comprise a single business enterprise; and (4) the "weakly integrated group" in which the subsidiaries are more autonomous and intercorporate associations are looser. Blumberg, The Law of Corporate Groups $\S 22.03 .3$ at 432 (cited in note 5).

16. Just as it is difficult to tell how much autonomy a particular subsidiary possesses, it is also difficult to determine where in the chain of corporate command a decision that has become the subject of litigation was made. Most parent-subsidiary relationships fall somewhere along a 
foreign subsidiary ceases to be a significant and distinct unit within the larger corporate operation, and instead functions as a division of a corporation with local managers responsible to remote division heads, the corporation's subsidiary status becomes more of a legal and accounting formality, thus making alter-ego status easier to prove. ${ }^{17}$

The article will now turn to a more in-depth analysis of the various jurisdictional theories, and their applications to securities litigation involving foreign entities, particularly subsidiary corporations.

\section{III}

\section{Jurisdictional Bases Under the 1934 ACt}

\section{A. Personal Jurisdiction: The Threshold of Minimum Contacts}

A plaintiff seeking the benefit and protection of the U.S. securities laws by suing a foreign subsidiary corporation bears the burden of making a prima facie showing through affidavits and supporting materials that a federal district court can exercise personal jurisdiction over the foreign defendant; ${ }^{18}$ absent such a showing, dismissal is proper under a Rule 12(b) motion. ${ }^{19}$ Because section 27 of the Securities Exchange Act of 1934 provides for worldwide service of process and extends personal jurisdiction to the limits of due process, ${ }^{20}$ the plaintiff's showing must consist of evidence that the

spectrum from total parental control, such that the subsidiary is a sham and makes only the most ministerial decisions independently, to those relationships in which the parent only determines the broadest budgeting and global policy, while the subsidiary retains exclusive control over its day-today operations. Determining when, where, and by whom a decision was made is often critical to jurisdictional analysis.

17. See Detlev F. Vagts, The Multinational Enterprise: A New Challenge for Transnational Law, 83 Harv L Rev 739, 752 (1970).

18. Courts generally will not allow plaintiffs to conduct a fishing expedition in an effort to manufacture a basis for personal jurisdiction. Mere speculation that a foreign defendant is subject to a federal court's jurisdiction in a securities matter, in the face of affidavit evidence conclusively to the contrary, necessitates denial of a request for discovery. Leema, 575 F Supp at 1537 (stating that a blanket, conclusive statement that personal jurisdiction was proper in a particular forum, absent any specific facts in support of the statement, could not confer personal jurisdiction). A threshold showing must be made that the plaintiff may be able to show personal jurisdiction if given further opportunity. Johnson Electric North America, Inc. $v$ Bank of Wales, PLC, WL 2006, 3 (SD NY 1991). Another factor courts might weigh in deciding whether to grant discovery is whether the information discovered as to the jurisdictional issue may shed light on a forum non conveniens motion pending in the same case. Id. Discovery requests in this area are generally decided on a case-by-case basis, owing to the often unique and peculiar facts of each case. For example, a foreign defendant may find itself trapped between answering a discovery request made by a U.S. court and obeying a law in its own country that necessitates that the defendant withhold the requested information. See, for example, In re Sealed Case, 825 F2d 494 (DC Cir 1987); Roe v United States, 484 US 963; Minpeco S.A. $v$ Conticommodity Services, Inc., 116 FRD 517 (SD NY 1987); see also Restatement (Third) of Foreign Relations Law $\S \$ 403,441,442$ (1986); Restatement (Second) of Foreign Relations Law $\S 39,40$ (1962).

19. FRCP 12(b); see Ball v Metallurgie Hoboken-Overpelt, S.A., 902 F2d 194, 197 (2d Cir 1990); Hoffritz for Cutlery, Inc. v Amajac, Ltd., 763 F2d 55, 57 (2d Cir 1985); Marine Midland Bank, N.A. v Miller, 664 F2d 899, 904 (2d Cir 1981); Landry v Price Waterhouse Chartered Accountants, 715 F Supp 98, 100 101 (SD NY 1989).

20. See note 4 and accompanying text. 
foreign subsidiary has sufficient minimum contacts with the United States as a whole to make the exercise of jurisdiction fair and reasonable. ${ }^{21}$

Minimum contacts with the United States necessary to confer personal jurisdiction in a securities action can arise if the foreign subsidiary commits an act demonstrating a purposeful availment of the privilege of conducting activities in the United States and an invocation of the benefit and protection of the securities laws. ${ }^{22}$ Under International Shoe ${ }^{23}$ and its progeny, a court may exercise general ${ }^{24}$ or specific jurisdiction ${ }^{25}$ based on the nature of the defendant's act(s) and contact(s) with the forum. In securities cases, the standard for general jurisdiction over a foreign subsidiary corporation ${ }^{26}$ is whether the subsidiary is conducting business or otherwise maintaining a presence in the United States. ${ }^{27}$ The standards for specific jurisdiction are:

21. Id; S.E.C. v Unifund Sal, 910 F2d 1028, 1033 (2d Cir 1990) (personal jurisdiction must be tested under minimum contacts analysis and due process standards); Perez-Rubio $v$ Wyckoff, $718 \mathrm{~F}$ Supp 217, 227 (SD NY 1989) (personal jurisdiction is asserted under $\$ 27$, which extends personal jurisdiction to the limits of the due process clause); Huang $v$ Sentinel Gov't Sec., 657 F Supp 485, 488 (SD NY 1987) (because $\$ 27$ extends personal jurisdiction to the limits of due process under the Fifth Amendment, the court must undertake a minimum contacts analysis).

The following securities cases illustrate the national, or aggregate contacts test: Leasco, 468 F2d at 1341-42; Perez-Rubio, 718 F Supp at 228; Paulson Inv. Co. v Norbay Securities, Inc., 603 F Supp 615 , 618 (D Ore 1984); Garner v Enright, 71 FRD 656, 660 (ED NY 1976); Alcoa Standard Corp. v Benalal, 345 F Supp 14, 24-25 (ED Pa 1972).

22. See Hanson v Denckla, 357 US 235, 253 (1958); Burger King Co. v Rudzewicz, 471 US 462, 474 (1985) ("[T]he constitutional touchstone remains whether defendant purposefully established 'minimum contacts' in the forum State."). Jurisdiction is proper where such contacts evince a "substantial connection" between the defendant and the forum state. Id at 475 . In turn, such "substantial connection" necessary to a finding of minimum contacts "must come about by an action of the defendant purposefully directed toward the forum State." Asahi Metal Indus. Co., Ltd. v Superior Court, 480 US 102, 112 (1987).

23. 326 US 310,318 (1945).

24. International Shoe, 326 US at 318 (General jurisdiction arises when the defendant's "continuous corporate operations within a state [are thought to be] so substantial and of such a nature as to justify suit against it on causes of action arising from dealings entirely distinct from those activities."); Helicopteros Nacionales de Colombia v Hall, 466 US 408, 415-17 (1984) (recognizing that "continuous and systematic general business contacts" in a forum make defendant present for all purposes).

25. International Shoe, 326 US at 318 (specific jurisdiction exists when defendant carries on "single or occasional acts ... [ [that,] because of their nature and quality, may be deemed sufficient to subject the non-resident defendant to personal jurisdiction on claims arising out of those activities").

26. The Restatement (Second) of Conflict of Laws $\$ \S 47,49,50$ supply the relevant jurisdictional standards for foreign subsidiary corporations. Leasco, $468 \mathrm{F2d}$ at 1340; Bersch v Drexel Firestone, Inc., 519 F2d 974, 998 (2d Cir 1975). Sections 35, 36, and 37 set forth the counterpart jurisdictional standards for other foreign defendants. Id. See also Reingold v Deloilte Haskins $\mathcal{E}$ Sells, 599 F Supp 1241, 1251 (2d Cir 1984).

27. With respect to causes of action arising from the business a foreign corporation conducts in a state, the state has power to exercise judicial jurisdiction over the foreign corporation. A state also has power to exercise judicial jurisdiction over a foreign corporation that does business in the state, with respect to causes of action that do not arise from the business done in the state, if this business is so continuous and substantial as to make it reasonable for the state to exercise such jurisdiction. Restatement (Second) of Conflict of Laws $\$ 47$. 
committing an act in the United States related to the transaction at issue, ${ }^{28}$ or committing an act elsewhere that has effects in the United States. ${ }^{29}$

\section{B. General Jurisdictional Presence: Agency and Alter-Ego}

Two theories of general jurisdiction that seek to establish a foreign subsidiary corporation's presence in the United States are agency and alterego. ${ }^{30}$ As a general principle, a foreign parent corporation (the principal) may be subjected to general jurisdiction in a federal court if it continuously and systematically conducted business within the forum through an agency relationship with a domestic subsidiary corporation (the agent). ${ }^{31}$ Traditional agency exists when the agent can act for and bind the foreign principal and when the agent's services in the forum are essential to the foreign corporation's business such that absent the agent's activities in the forum, the principal would need to enter the forum and perform those activities itself. ${ }^{32}$ However, courts will not apply such a theory in the reverse situation, i.e., when jurisdiction is sought over a foreign subsidiary based on its agency relationship with a domestic parent. ${ }^{33}$ Thus, in Reingold $v$. Deloitte Haskins $\mathfrak{E}$ Sells, a securities fraud suit involving accountant liability for audit reports used in U.S. securities filings, the Second Circuit rejected plaintiffs' argument that jurisdiction over a foreign agent was proper based on the acts of its U.S. principal. ${ }^{34}$ The court reasoned that whereas the principal operates independently of the agent, the agent operates at the behest of the principal and lacks the necessary control over the principal to form a sufficient jurisdictional basis. ${ }^{35}$

28. A state has power to exercise judicial jurisdiction over a foreign corporation that has done, or has caused to be done, an act in the state with respect to any cause of action in tort arising from the act. A state also has power to exercise judicial jurisdiction over a foreign corporation that has done, or has caused to be done, an act in the state with respect to any cause of action not in tort arising from the act unless the nature of the act and of the corporation's relationship to the state makes the exercise of such jurisdiction unreasonable. Id at $\S 49$.

29. A state has power to exercise judicial jurisdiction over a foreign corporation that causes effects in the state by an act done elsewhere with respect to any cause of action arising from the effects unless the nature of these effects and of the corporation's relationship to the state makes the exercise of such jurisdiction unreasonable. Id at $\S 50$.

30. Although apparently two separate principles, cases sometimes blur the distinction. Bulova Watch Co., Inc. v K. Hattori $\mathcal{O}^{2}$ Co., Ltd., 508 F Supp 1322, 1334 (ED NY 1981).

31. Wells Fargo \& Co. $v$ Wells Fargo Express Co., 556 F2d 406, 412-14 (9th Cir 1977); Product Promotions, Inc. $v$ Cousteau, 495 F2d 483, 492 (5th Cir 1974); Bulova Watch, 508 F Supp 1322.

32. See 1. Oliver Engebretson, Inc. $v$ Aruba Palm Beach Hotel Eं Casino, 587 F Supp 844, 850 (SD NY 1984); Arrow Trading Co. $v$ Sanyei Corp. (Hong Kong), Ltd., 576 F Supp 67, 70 (SD NY 1983); Pneuma-Flo Systems, Inc. v Universal Machinery Corp., 454 F Supp 858, 865 (SD NY 1978).

33. Reingold, $599 \mathrm{~F}$ Supp at 1253 (The court stated that it knew of no court that had actually applied the agency theory in reverse, where jurisdiction is sought over the nonresident agent for the jurisdictional presence of its principal.). See also Walker $v$ Newgent, 583 F2d 163 (5th Cir 1978); Blount v Peerless Chemicals (P.R.) Inc., 316 F2d 695 (2d Cir 1963) (adopting Judge Weinfeld's position in Grove Valve Es Regulator Co. v Iranian Oil Services, Ltd., 87 FRD 93, 96 (SD NY 1980)) ("While it is possible to find jurisdiction over a principal based on the acts in New York of its agent, . . this theory of jurisdiction is completely inapposite here where it is the alleged principal who does business in New York and the agent who does not.").

34. Reingold, 599 F Supp at 1253.

35. Id. 
Unlike the agency cases, jurisdictional analysis under an alter-ego theory is the same whether jurisdiction is sought over a foreign subsidiary of a domestic parent or over a foreign parent of a domestic subsidiary. ${ }^{36}$ In Reingold, for example, although the court could not even consider plaintiffs' argument for jurisdiction over a nonresident agent based on the acts of its resident principal, it conducted an extensive analysis of jurisdiction based on the same foreign entity's minimum contacts with the United States. ${ }^{37}$ Absent an agency theory, a court may not ascribe a domestic parent's actions to its foreign subsidiary unless it can show that the subsidiary functions as a "mere department" of the parent. ${ }^{38}$ In such circumstances, courts typically employ "piercing-the-veil" jurisprudence ${ }^{39}$ and hold that the foreign subsidiary was merely the alter-ego of the domestic parent who in fact disregarded the independent existence of the subsidiary. ${ }^{40}$ For example, in Titu-Serban Ionescu $v$. E.F. Hutton Company, Inc., the court exercised jurisdiction over Hutton (France), a wholly-owned subsidiary of Hutton (New York), by "piercing the corporate veil," and holding that Hutton (France) acted merely as a department, incorporated division, or instrumentality of its parent company based on the extent of control exercised by the parent, and the fact that Hutton's (New York) 10-K filings and annual reports repeatedly referred to Hutton (France) as a "branch" and a "division." 41

A strong, yet rebuttable, presumption of corporate separateness exists, and courts typically hesitate to characterize one corporation as another's alter-ego for jurisdictional purposes. ${ }^{42}$ That seems to be a sound practice. Before incurring the high transaction costs of incorporating, staffing, and

36. See Restatement (Second) of Conflict of Laws \$ 52, comment b; Saraceno v S. C. Johnson $\&$ Son, Inc., 83 FRD 65, 67 n5 (SD NY 1979); Titu-Serban Ionescu v E. F. Hutton \& Co., 434 F Supp 80, 83 (SD NY 1977); Freeman v Gordon E Breach, Science Publishers, Inc., 398 F Supp 519, 521 (SD NY 1975); Born \& Westin, International Civil Litigation at 110-11 (cited in note 5) (numerous cases cited therein).

37. Reingold, 599 F Supp at 1253.

38. Id; Volkswagenwerk Aktiengesellschaft v Beech Aircraft Corp., 751 F2d 117, 120 (2d Cir 1984); Blount v Peerless Chemicals (P.R.), Inc., 216 F Supp 612, 615 (ED NY 1962), aff'd, 316 F2d 695 (2d Cir 1963); Huang, 657 F Supp at 489; City of New York v Exxon, Corp., 633 F Supp 609, 620-21 (SD NY 1986); Bialek v Racal-Mingo, Inc., 545 F Supp 25, 31-32 (SD NY 1982); Sun First Nat'l Bank of Orlando v Miller, 77 FRD 430, 436 (SD NY 1978); Freeman, 398 F Supp at 521; Sunrise Toyota, Ltd. v Toyota Motor Co., 55 FRD 519, 528 (SD NY 1972).

39. When a parent does not treat a subsidiary as having a separate corporate existence and identity in fact, courts may conclude that the subsidiary's independent corporate form is a sham or fraud and "pierce" the subsidiary's "corporate veil." Courts show differing degrees of willingness to pierce a subsidiary's corporate veil. See Brunswick Corp. v Suzuki Motor Co., Ltd., 575 F Supp 1412, $1417 \mathrm{n} 3$ (ED Wis 1983).

40. Titu-Serban Ionescu, 434 F Supp at 81; Parada Jimenez v Mobil Oil Company de Venezuela, No. 90 Civ 5938 (SWK) (SD NY 1991) 1991 WL 64186.

41. Titu-Serban lonescu, $434 \mathrm{~F}$ Supp at 81-83.

42. See, for example, Reingold, $599 \mathrm{~F}$ Supp at 1254, quoting Walker $v$ Newgent, 583 F2d 163 (5th Cir 1978) ("A subsidiary corporation will not be regarded as the alter ego of its parent because of stock ownership, a duplication of some or all of the directors or officers, or an exercise of control that stock ownership gives to stockholders."); Blount, 316 F2d at 698-99; Parada Jimenez, 1991 WL 64186 (There is a strong presumption of corporate separateness and "[c]ourts will decline to exercise jurisdiction over a foreign subsidiary of a parent company which does business in New York unless plaintiff can rebut the presumption of corporate separateness."); Grove Valve E Regulator, 87 FRD at 95; Saraceno, 83 FRD at 67. 
operating a foreign subsidiary, parent corporations should be able to rely on the risk-shifting function of subsidiaries and should be able to predict with some certainty the fora in which a subsidiary is subject to suit. In general, as long as a corporation and its parent continue to operate as "distinct corporate entities," courts will not extend jurisdiction over the foreign subsidiary as though it were merely a department or alter-ego of the parent. ${ }^{43}$ Absent extensive control by the parent, the parent-subsidiary relationship alone is not sufficient to confer general jurisdiction over the foreign subsidiary. ${ }^{44}$ Some other jurisdictional basis is necessary.

Courts essentially conduct a factual inquiry to determine whether the economic connection between parent and subsidiary and the realities of control form a sufficient jurisdictional basis under an alter-ego analysis. ${ }^{45}$ For example, after analyzing several cases applying the alter-ego analysis, the Southern District of New York stated in HVIDE Marine International, Inc. $v$. Employer Insurance of Wausau ${ }^{46}$ that "the decision is essentially factual and requires a court to draw a line between truly separate corporations and subsidiaries which are not functionally independent." 47 The Second Circuit, in Titu-Serban Ionescu, held that "although two separate corporate entities have been established here, only one commonly owned enterprise exists which relies on the joint endeavors of each constituent part and each corporation functions as an integral part of a united endeavor." 48

Some commentators strongly argue that this evolving "enterprise" concept of the corporate group, which focuses on economic realities and control in contrast to the "entity" concept, which focuses on formalisms, is a sounder approach to jurisdictional analysis in parent-subsidiary relationships and is now strongly rooted in the law. ${ }^{49}$ Although that approach may be sound from a practical perspective, courts should not neglect the

43. See Bulova Watch Co., Inc. v K. Hattori E' Co., Ltd., 508 F Supp 1322, 1342 (ED NY 1981) (Parent corporations that observe a strict formal separation from their subsidiaries and that derive no direct benefit therefrom are not subject to in personam jurisdiction); Kramer Motors, Inc. $v$ British Leyland, Ltd., 628 F2d 1175, $1177-78$ (9th Cir 1980); Perfumer's Workshop v Roure Bertrand du Pont, Inc., 737 F Supp 785, 788 (SD NY 1990) (considered jurisdiction over a foreign corporation under the Sherman Antitrust Act); Huang, 657 F Supp at 489-90.

44. Volkswagenwerk Aktiengesellschaft, 486 US at 705-06 $\mathrm{n}$ (1988); see also Consolidated Textile Co. $v$ Gregory, 289 US 85, 88 (1933); Cannon Mfg. Co. v Cudahy Co., 267 US 333, 336 (1925); Morse Typewriter Co. v Samanda Office Communications, 629 F Supp 1150, 1156 (SD NY 1986) (mere stock ownership relationship insufficient to satisfy Hanson $v$ Denckla due process requirements; see note 21); Freeman, 398 F Supp at 521; Restatement (Second) of Conflict of Laws $\$ 52$ comment b.

Moreover, mere approval by the parent of certain transactions or plans of a subsidiary generally seems to be an insufficient jurisdictional basis. See, for example, Aurora Enterprises, Inc. $v$ Nat'l Broadcasting Co., 688 F2d 689, 696 (9th Cir 1982); Kramer Motors, 628 F2d at 1178 (9th Cir 1980); Huang, 657 F Supp at 490; Allen v Toshiba Corp., 599 F Supp 381, 391-92 (D NM 1984); Doll v James Martin Associates, 600 F Supp 510, 517-18 (ED Mich 1984).

45. HVIDE Marine International, Inc. v Employer Insurance of Wausau, 724 F Supp 180, 185 (SD NY 1989); Bulova Watch, 508 F Supp at 1334.

46. 724 F Supp 180, 185 (SD NY 1989).

47. HVIDE Marine, $724 \mathrm{~F}$ Supp at 185.

48. Titu-Serban Ionescu, 434 F Supp at 82 (emphasis added).

49. See generally Blumberg, The Law of Corporate Groups (cited in note 5) (entire volume devoted to this subject); Charles I. Wellborn, Subsidiary Corporations in New York: When is Mere Ownership Enough to Establish Jurisdiction over the Parent?, 22 Buff L Rev 681 (1973). 
corporation's need to predict its liability in a given transaction. Therefore, in the interest of fairness and normative consistency, courts should ignore formalism only in the most extreme situations.

Although the alter-ego inquiry is highly fact specific, general guiding principles and discrete areas of analysis exist. Essentially, the inquiry centers around economic integration, intrusion by the parent into the subsidiary's day-to-day decisionmaking, and the public posture of the subsidiary as an individual unit or merely a branch or division of the parent. ${ }^{50}$ Unfortunately, the chances of finding precedent directly on point in this area may be remote, owing to the fact-specific nature of each inquiry. However, a well-structured motion grounded upon these basic principles has a better chance of success.

\section{Specific Jurisdiction: Acts or Effects in the United States}

A foreign subsidiary's commission of an act in the United States, and the causing of effects in the United States by executing a transaction abroad are the two basic theories of specific jurisdiction. In the first instance, action in the forum ${ }^{51}$ sufficient to confer personal jurisdiction may include the foreign corporation or its agents participating in meetings and negotiations or engaging in various types of communications with persons in the United States. ${ }^{52}$ However, in order for those acts to form an appropriate jurisdictional basis, the cause of action must arise specifically out of those acts, or the transaction associated with those acts. ${ }^{53}$ For example, in Reingold, the court could not exercise jurisdiction because the foreign defendant's telexes and telephone calls to the United States did not relate to the allegedly defective audit report that formed the basis for plaintiffs' securities fraud action. ${ }^{54}$

Jurisdiction over a foreign subsidiary corporation in a securities-fraud action may exist based on acts committed by that entity's co-conspirators in the United States pursuant to a conspiracy to defraud. ${ }^{55}$ For example, in

50. See Blumberg, The Law of Corporate Groups $\$ 1.02 .1$ at 9.20 (cited in note 5) (discussing the "common identity" alternative for jurisdictional purposes); HVIDE Marine, 724 F Supp at 185 ("While a parent corporation will rightfully decide the broad policy objectives for its subsidiaries, excessive involvement in the day-to-day operations of a subsidiary can indicate that the alleged independence is only formal.").

The Second Circuit has identified the following major areas of inquiry: (1) whether parent and subsidiary ownership interests are identical; (2) to what degree the subsidiary is financially independent of the parent (in other words, whether the subsidiary operate on its own); (3) to what degree the parent corporation interferes in the selection and assignment of the subsidiary's executive personnel; (4) to what extent the parent fails to observe corporate formalities; and (5) to what degree the parent controls the marketing and operational policies of the subsidiary. Volkswagonwerk Aktiengesellschaft, 751 F2d at 120-22.

51. Restatement (Second) of Contracts $§ 49$ (1971).

52. Reingold, 599 F Supp at 1254.

53. See, for example, Bersch, 519 F2d at 999-1000; Huang, 657 F Supp at 488; Reingold, $599 \mathrm{~F}$ Supp at 1254 .

54. Reingold, 599 F Supp at 1254 .

55. Leasco, $468 \mathrm{~F} 2 \mathrm{~d}$ at 1343 (stating that jurisdiction on a conspiracy theory in a securities case is possible); Allstate Life Ins. Co. v Linter Group, Ltd., 782 F Supp 215, $220-23$ n6 (SD NY 1992) (conspiracy theory is equally appropriate when jurisdiction is sought under NY CPLR $\S 302$ or $\S 27$ 
Allstate Life Insurance Co. $v$. Linter Group, Ltd., a very recent Southern District of New York securities fraud case, the court relied exclusively on a conspiracy theory to exercise personal jurisdiction over several foreign corporate subsidiaries including an Australian Bank operating exclusively in Australia as a wholly-owned subsidiary of a British parent bank that conducted business in the United States. ${ }^{56}$ In Allstate, the court never reached the numerous other jurisdictional arguments put forth by the parties once it found that all the elements of conspiracy had been pleaded. ${ }^{57}$

Moreover, a bald assertion of conspiracy is insufficient to confer jurisdiction. ${ }^{58}$ Similarly, the mere presence of one conspirator in the United States for jurisdictional purposes does not automatically confer jurisdiction over another conspirator located abroad. ${ }^{59}$ Rather, the plaintiff must generally make a prima facie showing of conspiracy, allege specific facts showing that defendants were members of that conspiracy, and show that the defendant's co-conspirator, who is present in the United States, committed a tortious act in furtherance of the conspiracy. ${ }^{60}$ In general, courts disagree over what elements are necessary to prove a civil conspiracy to violate the securities laws. ${ }^{61}$

In limited circumstances a court may exercise jurisdiction over a foreign subsidiary corporation that has caused effects in the United States by its actions abroad.62 However, not every causal connection between an action abroad and injury to U.S. investors will confer personal jurisdiction on a foreign defendant. ${ }^{63}$ Even assuming some causal relation, the test for personal jurisdiction is somewhat more demanding. ${ }^{64}$ For example, mere foreseeability of injury, as defined in the context of proximate causation and tort liability, would probably not be a sufficient benchmark for personal jurisdiction. Rather, the causal nexus required is that the harms complained of occurred as a "direct and foreseeable result of the conduct outside the territory," 65 and the foreign corporation must "know, or have good reason to

of the Exchange Act); Chrysler Capital Corp. v Century Power Corp., 778 F Supp 1250, 66 (SD NY 1991); Grosser v Commodity Exc, Inc., 639 F Supp 1293 (SD NY 1986); Singer v Bell, 585 F Supp 300 (SD NY 1984) ("It is well established 'that the acts of a co-conspirator may be attributed to a defendant for the purpose of obtaining personal jurisdiction over the defendant." ").

56. Allstate, $782 \mathrm{~F}$ Supp at 223.

57. Id.

58. Lehigh Valley Indus., Inc. v Birenbaum, 527 F2d 87, 93-94 (2d Cir 1975); Chrysler Capital, 778 F Supp at 1266; Allstate, 782 F Supp at 221.

59. Leasco, 468 F2d at 1343; H.L. Moore Drug Exchange, Inc. v Smith, Kline E French Laboratories, 384

F2d 97 (2d Cir 1967); Bertha Bldg. Corp. v Nat'l Theaters Corp., 248 F2d 833, 836 (2d Cir 1957).

60. Allstate, 782 F Supp at 221.

61. Id (numerous cases cited therein).

62. Restatement (Second) of Conflict of Laws § 37. But as the Leasco court noted, " $[t]$ his is a principle that must be applied with caution particularly in the international context." Leasco, $468 \mathrm{~F} 2 \mathrm{~d}$ at 1341.

63. Unifund Sal, 910 F2d at 1033

64. Bersch, $519 \mathrm{~F} 2 \mathrm{~d}$ at $998-1000$.

65. Leasco, 468 F2d at 1341 (citing Restatement (Second) of Foreign Relations Law § 18(b)(iii)); see also Unifund Sal, 910 F2d at 1033 (sufficient causal relationship demonstrated because Lebanese investment company's alleged trading of options in a U.S. corporation listed exclusively on a U.S. stock exchange on the basis of inside information created the near certainty that U.S. shareholders 
know, that [its] conduct will have effects" in the United States. ${ }^{66}$ Under such a standard, incidental communications between a parent present in the United States and its foreign subsidiary that described or sought approval for the transaction complained of could not support a finding of jurisdiction, absent a showing that the subsidiary was the alter-ego or mere department of the parent. ${ }^{67}$

\section{IV}

\section{Reasonableness and the Forum Non Conveniens Doctrine}

The minimum contacts analysis and the forum non conveniens analysis ultimately ask whether compelling the appearance of defendants in a U.S. court would be fair and reasonable. Operating together, those two inquiries provide a two-level system of checks on the extension of personal jurisdiction over foreign corporations. 68 Because the application of each analysis potentially allows another nation's courts to step into the litigation, the policy considerations discussed in Part IV of this article should be highlighted when arguing either motion.

\section{A. Reasonableness}

In any minimum contacts analysis in a securities case, courts ultimately consider whether extending personal jurisdiction over a foreign subsidiary

would be adversely affected); Bersch, 519 F2d at 1000 (effects should flow directly from the acts done outside the jurisdiction); Huang, $657 \mathrm{~F}$ Supp at $489 \mathrm{n3}$.

The minimum is that required by the Restatement (Second) of Foreign Relations Law § 18(b) which states that "(ii) the effect within the territory is substantial; (iii) it occurs as a direct and foreseeable result of the conduct outside the territory; and (iv) the rule is not inconsistent with the principles of justice generally recognized by states that have reasonably developed legal systems." See also Bersch, 519 F2d at 1000; Restatement (Third) of Foreign Relations Law $\S 402$ (1)(c) (" state has jurisdiction to prescribe law with respect to ... (c) conduct outside its territory that has or is intended to have substantial effect within its territory.").

66. Leasco, $468 \mathrm{~F} 2 \mathrm{~d}$ at 1341.

67. Huang, 657 F Supp at 490-91.

68. It is important to note that the doctrine of forum non conveniens can never apply in the absence of personal jurisdiction over the parties. Gulf Oil Corp. v Gilbert, 330 US 501, 504 (1947). Therefore, a district court must first decide whether it has jurisdiction over the defendants. Allstate, 782 F Supp at 219; Monsanto Int'l Sales Co., Inc. v Hanlin Container Lines, Ltd., No 88 CIV 1673, 1991 US Dist LEXIS 14189 at *3 (SD NY Oct 1991); Charles Wright, Arthur Miller \& Edward H. Cooper, Federal Practice and Procedure $\S 3828$ (West, 1986). In light of the similarities between the reasonableness prong of minimum contacts and forum non conveniens, and in the interest of promoting judicial economy, defendants may consider structuring their Rule 12(b) motion to dismiss as a combined motion, coupling their forum non and personal jurisdiction arguments. In multidefendant international litigation, jurisdictional facts may differ among defendants such that a joint personal jurisdiction motion is impractical. However, even in such situations, a joint motion to dismiss for forum non conveniens is strongly urged because it saves costs to the client and allows for judicial economy. As a practical reality, deciding a forum non conveniens motion is a judicially economical way for a congested district court to dispose of a complex multinational litigation. Whether the forum non conveniens and personal jurisdiction arguments are filed as separate or combined motions, they should stress the unique burdens on them as international defendants, the nature and quality (or lack thereof) of their contacts with the United States, the relation of those contacts with the alleged cause of action, and the overall unfairness of compelling their appearance in a U.S. court. 
corporation would be fair and reasonable and comport with due process. ${ }^{69}$ Particularly where the jurisdictional basis consists of acts abroad causing effects within the United States, the reasonableness analysis is guided by Justice O'Connor's admonition that "[g]reat care and reserve should be exercised when extending our notions of personal jurisdiction into the international field."70 Perhaps the most important part of this inquiry is that the defendant's contact within the United States in a given securities transaction must be "such that he should reasonably anticipate being haled into court there." 71 When inquiring under minimum contacts and due process, courts labor to unearth the relationship among "the defendant, the forum, and the litigation."72 For example, in Bersch $v$. Drexel Firestone, Inc., the Second Circuit held that it would be unreasonable to extend personal jurisdiction over a Canadian investment-banking house because the defendant had no knowledge that purchasers of its underwriting would be U.S. citizens. ${ }^{73}$ In contrast, the Southern District of New York, in Perez-Rubio $v$. Wyckoff, exercised jurisdiction over several foreign defendants in a securitiesfraud suit by finding that each defendant could foresee that its actions would cause effects within the United States, could reasonably anticipate being haled into a U.S. court, and that the contacts each had with the United States were not so "random, fortuitous, or attenuated" as to make the maintenance of a suit unreasonable. ${ }^{74}$ Furthermore, in Securities $\mathcal{E}^{*}$ Exchange Commission $v$. Gilbert, ${ }^{75}$ the Southern District of New York found jurisdiction over a Swiss bank by reasoning that because the securities fraud action arose out of the Bank's contacts with the United States, namely, the purchase and sale of securities through four service accounts maintained in the United States, those contacts made it fair to require defense of the action in federal court. ${ }^{76}$ The Gilbert court concluded its jurisdictional analysis by stating that " $[n]$ othing in the nature of Bank Union's contacts with this forum suggests that the exercise of . . jurisdiction is 'unreasonable.',"77

69. Bersch, 519 F2d at 1000 . See notes 23, 24, 25, and 26 (Each Restatement section ends by stating that the extension of jurisdiction must be reasonable); see also International Shoe, 326 US at 316 (exercise of personal jurisdiction is inappropriate and violative of due process where haling a foreign defendant into court would offend "traditional notions of fair play and substantial justice"), quocing Miller v Mayer, 311 US 457, 463 (1940); Burger King, 471 US at 477-78 ("[M]inimum requirements inherent in the concept of 'fair play and substantial justice' may defeat the reasonableness of jurisdiction even if the defendant has purposefully engaged in forum activities."'); Reingold, 599 F Supp at 1251 ("Although the Restatement successfully distills the Supreme Court's edicts regarding personal jurisdiction into a set of helpful guidelines . . . the Supreme Court's pronouncements continue to weigh heavily in this area.").

70. Asahi, 480 US at 115, quoting United States v First National City Bank, 379 US 378 (1965); see also Bersch, 519 F2d at 1000; Leasco, 468 F2d at 1341; Huang, $657 \mathrm{~F}$ Supp at $489 \mathrm{n} 3$.

71. Landry, 715 F Supp 98, 101 (SD NY 1989), quoting World-Wide Volkswagen Corp. $v$ Woodson, 444 US at 297.

72. Reingold, 599 F Supp at 1251, quoting Calder v Jones, 465 US 783, 788 (1984); Keeton v Hustler Magazine, 465 US 770, 780 (1984), both quoting Shaffer $v$ Heilner, 433 US 186, 204 (1977).

73. Bersch, 519 F2d at 1000 .

74. Perez-Rubio, 718 F Supp at 227-31.

75. 82 FRD 727, 725 (SD NY 1979).

76. Id at $725-26$.

77. Id at 726, citing Restatement (Second) of Conflict of Laws $\$ 37$. 
Although the thrust of the "reasonableness" analysis centers around the relationships among the defendants, the forum, and the cause of action, the inconvenience and burdens of international litigation should also be considered. As the Supreme Court has stated, "The unique burdens placed upon one who must defend oneself in a foreign legal system should have significant weight in assessing the reasonableness of stretching the long arm of personal jurisdiction over national borders."78 This is primarily because the differences in legal culture ${ }^{79}$ and the great distances involved ${ }^{80}$ expose an international defendant to greater litigation hardships than a traditional U.S. out-of-state defendant.

However, these considerations should not be overemphasized particularly where subsidiaries of large U.S. corporations are concerned. Such foreign corporations generally have ready access to sophisticated U.S. counsel and all the tools of modern communications, enabling them to surmount some of the challenges posed by differing legal cultures and distance. Moreover, the cost of shuttling witnesses overseas and the cost of production may be relatively minor compared to the assets of the entire corporate group. As a global economy continues to develop, perhaps firms will recognize and prepare more fully for the increasing chance of being haled into a foreign forum.

\section{B. The Forum Non Conveniens Doctrine}

Federal district courts can dismiss private claims alleging violations of the 1934 Act under the doctrine of forum non conveniens. ${ }^{81}$ When applying the

78. Asahi, $480 \mathrm{US}$ at 114

79. For instance, a foreigner may be unfamiliar with procedural rules, substantive law, the scope of liability, the amount of damages awardable, as well as face an obvious language barrier and a systemic national bias in a U.S. court.

80. Time differences, mail delays, transportation and production expenses, and other logistical problems, for example.

81. Howe $v$ Goldcorp Inv., Ltd., 946 F2d 944, 948-50 (1st Cir 1991) (forum non conveniens dismissal to Canada in a private securities fraud suit where SEC argued that the doctrine could not be applied to private securities cases. The court stated that " $[\mathrm{t}] \mathrm{he}$ growing interdependence of formerly separate national economies, the increased extent to which commerce is international, and the greater likelihood that an act performed in one country will affect citizens of another, all argue for expanded efforts to help the world's legal systems work together, in harmony, rather than at cross purposes.") Id at 950.

The doctrine of forum non conveniens applies to cases originally brought under the federal securities laws, as well as other federal statutes with similar jurisdictional reach. Schoenbaum $v$ Firstbrook, 405 F2d 200, 209 n5 (2d Cir 1968); see Transunion Corp. v Pepsico, Inc., 81 1 F2d 127, 130 (2d Cir 1987) (forum non conveniens applicable to RICO claims even though treble damages available under RICO and not in foreign forum); Fidenas $A G$ v Compagne Int' $l$, Etc. 606 F2d 5, 6 (2d Cir 1979) (district court considered defendant's forum non conveniens argument in securities case “persuasive"); Wells Fargo E' Co. $v$ Wells Fargo Express Co., 556 F2d 406, 431 (9th Cir 1977) (forum non conveniens applicable to actions under the Lanham Act even though special venue provision existed); DeYoung v Beddome, 707 F Supp 132, 132-37 (SD NY 1989) (federal securities law claim dismissed on, inter alia, forum non conveniens grounds where alternative forum recognized general fraud and misrepresentation causes of action); Fustok v Banque Populaire Suisse, 546 F Supp 506, 513 14 (SD NY 1982) (forum non conveniens applicable to federal claim under Commodities Exchange Act even if Swiss Court would not apply the Act); but see S.E.C. $v$ Wimer, 75 F Supp 955, 963-65 (WD $\mathrm{Pa}$ 1948) (suggesting that Securities Act's special venue provision barred forum non conveniens dismissal); Pioneer Properties, Inc. v Martin, 557 F Supp 1354, 1362 (D Kan 1983) (similar language). 
doctrine, a district court performs essentially the same analysis as it does under a minimum contacts and reasonableness inquiry when considering a motion to dismiss for lack of personal jurisdiction. Courts first determine the extent of the parties' contacts with the United States and the basic circumstances out of which plaintiff's claim developed, and then consider whether conducting the litigation in the chosen forum would be inconvenient and unfair. The difference between the two analyses is that with reasonableness, courts keep in line with International Shoe and its progeny and focus on the foreseeability of suit in the United States, ${ }^{82}$ whereas the forum non conveniens inquiry focuses solely on convenience. For example, in Howe $v$. Goldcorp Investments, Ltd. ${ }^{83}$ a case dismissing a Canadian corporation in a securities-fraud case for forum non conveniens, the First Circuit structured its analysis by first discussing at length the complex relationship between the defendants' contacts with the United States and the cause of action brought by plaintiff, and then considering whether plaintiff was forcing trial at the most inconvenient place. ${ }^{84}$ However, the Howe court never reached any of the due process questions of foreseeability of suit because it had already determined that jurisdiction in accordance with due process existed over the foreign defendants.

The forum non conveniens doctrine empowers a district court to dismiss an entire action, despite the presence of jurisdiction and venue. ${ }^{85}$ In that regard, the doctrine functions as the ultimate, and perhaps most important, check on the improper assertion of personal jurisdiction. Forum non conveniens dismissal is proper if, after weighing various "private" interests and "public" interests, a court determines that plaintiff is "forcing the trial at a most inconvenient place for an adversary." 86 Unless the balance tips "strongly" in favor of another forum, courts will rarely disturb a plaintiff's choice. ${ }^{87}$ Dismissal is committed to the sound discretion of the trial court; reversal is appropriate only where there has been clear abuse and an unreasonable weighing of the factors considered. ${ }^{88}$

82. Worldwide Volkswagen $v$ Woodson, 444 US 286, 297 (1980) (One process seeks to give predictability to the legal system. Potential defendants should have some certainty of where their conduct will subject them to suit.).

83. 946 F2d 944.

84. Id ("To understand the basis for our conclusion that dismissal of the entire case was lawful, the reader must keep in mind background circumstances that involve complex relationships among three factors: (1) Goldcorp's contacts with the United States; (2) the basic circumstances out of which Mr. Howe's claims developed; and (3) Mr. Howe's several different, specific legal claims."); compare Huang, $657 \mathrm{~F}$ Supp at $\mathbf{4 8 8 - 8 9}$ (due process satisfied only when there is a "significant causal relation between defendant's jurisdictional contacts and plaintiffs' cause of action").

85. Howe, $946 \mathrm{~F} 2 \mathrm{~d}$ at 947.

86. Gulf Oil, 330 US at 507. To guide trial court discretion, the Gulf Oil court provided a list of "private interest factors" affecting the convenience of the litigants and a list of "public interest factors" affecting the convenience of the forum. Id at 508-09; see also Piper Aircraft $v$ Reyno, 454 US 235, 245 n6 (1981).

87. Alfadda v Fenn, [1991-1992] Fed Secur L Rptr (CCH) ๆ 96,625 and 92,931 (SD NY Feb 21, 1992).

88. Howe, 946 F2d at 951 . 
The private-interest factors dominate the analysis, centering primarily around the relative availability of sources of proof and other practical burdens of international litigation. ${ }^{89}$ The primary factor to be considered is the difficulty of securing the attendance of witnesses, especially key witnesses, living abroad. ${ }^{90}$ Securing the attendance of witnesses at securities fraud trials is of special concern because of the importance of assessing witness demeanor during such trials. ${ }^{91}$ In the extreme situations, when a court is unable to compel the attendance of witnesses due to jurisdictional limitations, dismissal for forum non conveniens may be the only alternative. ${ }^{92}$ The lack-ofcompulsory-process argument is a two-edged sword, however. Courts may find that factor of little importance when the alternative forum lacks compulsory process over an equal number of witnesses. ${ }^{93}$

The location of documents ${ }^{94}$ and the relative ease of discovery also factor into a court's analysis. Document location, however, should assume significance in the court's calculus only when the amount of document production is vast. ${ }^{95}$ Similarly, discovery that can be done only by letters

89. A litigant's private interests may include "the relative ease of access to sources of proof; availability of compulsory process for attendance of unwilling, and the cost of obtaining attendance of willing, witnesses; ... and all other practical problems that make trial of a case easy, expeditious and inexpensive. There may also be questions as to the enforceability of a judgment if one is obtained." Gulf Oil, 330 US at 508.

90. See, for example, Overseas National Airways. Inc. $v$ Cargolux Airlines Int'l., 712 F2d 11, 12 (2d Cir 1983) (witnesses in Luxembourg or other parts of Europe); Calavo Growers of California v Belgium, 632 F2d 963, 967 (2d Cir 1980) (witnesses in Belgium); Fitzgerald v Texaco, Inc., 521 F2d 448, 451-2 (2d Cir 1975) (witnesses in England); Interpane Coatings v Australia E New Zealand, 732 F Supp 909, 916 (ND Ill 1990) (witnesses in Australia); Winex, Ltd. v Paine, No 89-2083, slip op at 6 (ED Pa Aug 15, 1990) (witnesses in England); DeYoung, 707 F Supp at 138-39 (witnesses in Canada); Transamerica ICS, Inc. v Tugu Insurance Co, 588 F Supp 1301, 1303-4 (SD NY 1984) (witnesses in Hong Kong); Fuslok, 546 F Supp at 513-14.

91. "When fraud charges are made, it is desirable that the fact finder have the benefit of demeanor testimony of witnesses who would be available in [the foreign forum] and not in the United States." Fustok, 546 F Supp at 511.

92. Gulf Oil, 330 US at 51 ("Certainly to fix the place of trial at a point where litigants cannot compel personal attendance and may be forced to try their cases on depositions is to create a condition not satisfactory to the court, jury or most litigants."); Howe, 946 F2d at 951 (except for plaintiff, no U.S. resident had knowledge of the matters complained of and U.S. courts lacked compulsory process over potential Canadian witnesses); Schertenleib $v$ Traum, 589 F2d 1156, 1165 (2d Cir 1978) ("inability to bring [witnesses] here for live cross examination before a fact-finder" is "[p]erhaps the most significant problem" and "a very serious handicap" warranting dismissal); Farmanfarmaian v Gulf Oil Corp., 588 F2d 880, 881 (2d Cir 1978) (the fact that major witnesses would most likely come from a foreign country weighed heavily in favor of declining jurisdiction); Zaveri $v$ E.F. Hutton Ė Co., [1986-87 Transfer Binder] Commodity Future L Rptr (CCH) I 22,976 (SD NY 1986) (key witnesses could not be summoned in New York, only in Dubai); Fustok, 546 F Supp at 510 nn $10-11)$.

93. See, for example, Allstate, 782 F Supp at 225.

94. Calavo Growers, 632 F2d at 967; Pain v United Technologies Corp., 637 F2d 775, 786-88 (DC Cir 1980) (" $[T]$ he inability of both parties to obtain a full panoply of relevant ... evidence would greatly hinder fair resolution of the dispute."); Dahl v United Technologies Corp., 632 F2d 1027, 1030 (3rd Cir 1980) (similar language).

95. When jurisdiction is sought over a large foreign subsidiary corporation which can easily assume the relatively minor costs of transporting documents overseas, document location is of less importance. See Allstate, 782 F Supp at 225 ("[I]n light of the advances in transportation and communication since 1947, the year Gulf Oil was decided, [ease of access to the sources of proof] will be accorded less weight in this Court's calculus."); Overseas Programming Co. v Cinematoaranhische 
rogatory, ${ }^{96}$ where the foreign sovereign is not a signatory of to the Hague Convention on the Taking of Evidence Abroad in Civil or Commercial Matters, ${ }^{97}$ may prove cumbersome enough to warrant dismissal. ${ }^{98}$ The extra costs of hiring local counsel in the foreign defendant's home nation as well as duplicate costs of hiring U.S. counsel must also be considered.99 Plaintiffs should argue that they have a paramount interest in litigating in a U.S. federal forum due to the liberal damages provisions of the 1934 Act and the expertise of federal courts in securities law cases.

The other salient prong to the private-interest analysis is the adequacy of the alternative forum and remedy. The doctrine of forum non conveniens presupposes that there are "at least two forums in which the defendant is amenable to process." 100 Dismissal may not be proper if there is a substantial danger that the litigants would be treated unfairly in the alternative forum ${ }^{101}$ due to gross systemic defects in the foreign nation's courts. ${ }^{102}$ The existence of less favorable liability theories, less-favorable remedies, or a lower probability of recovery will not defeat a motion to dismiss for forum non conveniens unless the prevailing procedures are so inherently unfair that in fact no remedy exists at all. ${ }^{103}$ For example, in Howe, the First Circuit dismissed a securities fraud action in favor of a Canadian firm after conceding the marked differences between Canadian and U.S. securities laws. ${ }^{104}$ For that reason, it seems unnecessary for corporate defendants to argue in their Rule 12(b) motions that an action could be brought under the 1934 Act in a

Commerzanstalt, 684 F2d 232 nl (2d Cir 1982); Manu Int'l, S.A. v Avon Products, Inc., 641 F2d 62, 65 (2d Cir 1981).

96. Letters rogatory are commissions from one judge to another in a foreign country requesting the foreign judge to examine a witness. See FRCP 28(b), 28 USCA $\$ 1781$.

97. See [1972] 23 UST 2555, TIAS No 7444 (1970).

98. Transunion Corp., 811 F2d at 129; DeYoung, 707 F Supp at 138-9.

99. Gulf Oil, 330 US at 508 .

100. Id at 506-07.

101. Piper, 454 US at 254-55.

102. There appears to be a low threshold of proof for this test, however. See, for example, In re Union Carbide Corp. Gas Plant Disaster at Bhopal, 809 F2d 195, 202-04 (2d Cir 1986) (India determined to be a reasonably adequate alternative forum over defendant's protests that the Indian court system did not observe traditional due process standards regularly observed by U.S. courts).

103. Smaller damage awards, the possibility of an unfavorable change in the foreign forum's law, different theories of liability, and a lower probability of recovering attorney's fees are not relevant to the calculus. See Piper, 454 US at 250-54 ("Only where the remedy provided by the alternative forum is so clearly inadequate or unsatisfactory that it is no remedy at all," should a court give weight to any difference in laws); Kempe v Ocean Drilling E Exploration Co., 876 F2d 1138, 1145 (5th Cir 1989); Dowling v Richardson-Merrell, Inc., 727 F2d 608, 615 (6th Cir 1984); Alcoa Steam Ship Co., Inc. $v M / V$ Nordic Regent, 654 F2d 147, 159 (2d Cir 1980) (en banc); Fitz, 521 F2d at 453; Fustok, 546 F Supp at $510 \mathrm{n} 10$.

104. Howe, 946 F2d at 952 (citing numerous cases). 
foreign country's courts ${ }^{105}$; the existence of a remedy is all that need be shown. ${ }^{106}$

The chief public-interest factors considered are court congestion and local interest in the controversy. ${ }^{107}$ Regarding congestion, a court may consider whether a securities case involving international corporate defendants would take substantially longer than the district's average. ${ }^{108}$ When analyzing the local interest in the controversy, the court must consider the litigant's contacts with the United States. In Howe, after examining in some depth the nature of defendants' contacts with the United States and Canada, the court concluded that the U.S. interest in the securities fraud action was low, while Canada's interest was comparatively high. ${ }^{109}$ The court noted that the underlying actions of defendants were governed by Canadian corporate law and best handled by Canadian courts. ${ }^{110}$ Conversely, in Allstate, the Southern District of New York recently stressed that where all plaintiffs who had places of business in the United States had purchased debentures from a U.S. underwriter, pursuant to a registration statement and prospectus filed in the United States, and where the alleged misrepresentations had occurred in the United States and had defrauded U.S. investors, the federal courts had a "substantial interest" in hearing the case."11 Although the United States has a

105. Some courts and experts agree that a remedy under the securities laws of the United States would be available in a foreign court system. See Howe, 946 F2d at 952 (citing Restatement (Second) of Conflict of Laws $\$ 6$ and Canada Malting Co. v Paterson Steamship, Led., 285 US 413, 424 (1932) (Canadian courts may apply antifraud provisions of Exchange Act)); Peter E. Nygh, Conflict of Laws in Australia (Butterworths, 5th ed 1991) 232, $217-18$ (discusses the application of foreign remedies in Australian courts); but see Leasco, 468 F2d at 1344 (in considering forum non conveniens arguments, the Second Circuit noted that an English court "might not apply" rule 10b-5).

This type of argument may be more appropriate on the appellate level due to its theoretical and academic nature. Also, some judges may not be predisposed to accept such an argument considering the exclusive federal jurisdiction provisions of the 1934 Act and may not dismiss if they are uneasy about a foreign court applying such laws. See Allstate, $782 \mathrm{~F}$ Supp at 224 ("That federal law claims are at the heart of the complaint here, however, is a factor to be considered by the Court in making its determination."); CL-Alexanders Laing E Cruickshank v Goldfeld, 709 F Supp 472, 481 (SD NY 1989) (in cases where the securities laws claims are not simply "window dressing" but are at "the heart of the complaint," a federal court has a strong public interest in ensuring that U.S. plaintiffs do not have to rely on the vagaries of foreign law).

106. For example, a motion to dismiss a securities fraud action to an Australian forum must allege that the common law remedy of contract recision and punitive damages exists for fraudulent misrepresentation in Australia, as well as a remedy under $\$ 52$ of the Trade Practices Act of 1974 for misleading or deceptive conduct. Trade Practices Act 1974, No 51. 1974 Austl Acts P 397. Similarly, Canadian laws provide some antifraud and fiduciary protections for shareholders. See Securities Act, RSO 1980, ch 466, §§ 126-27, 131-32; Business Corporations Act, RSO 1982, ch 4, $\S \S 134,244-47,252$.

107. Piper, 454 US at $241 \mathrm{n} 6$; Gulf Oil, 330 US at 509.

108. For example, in the Southern District of New York, the time between joinder of issue and trial in a civil action is typically 19 months. Annual Report of the Director of the Administrative Office of the United States Courts at $172(1990)$. However, some parts of the federal judiciary in a given district do not experience significant delays in proceeding to trial and have current calendars. See Allstate, $782 \mathrm{~F}$ Supp at 225 ("There is no delay for trial in this part nor has there been for over one year. Upon completion of discovery this case will be scheduled for trial immediately. Accordingly, the Court does not consider calendar congestion a factor which favors dismissal.").

109. Howe, $946 \mathrm{~F} 2 \mathrm{~d}$ at 953.

110. Id.

111. Allstate, $782 \mathrm{~F}$ Supp at 225 ("This court has a substantial interest in affording United States citizens a forum, in enforcing the federal securities laws, and in preserving the integrity of markets 
paramount interest in resolving cases involving violations of its own securities laws, if the foreign defendant is a major corporation, the foreign sovereign may have a great interest in regulating the defendant's conduct and resolving the issues. ${ }^{12}$ That should hold true especially in actions alleging fraudulent schemes where foreign relations with the United States are at stake.

\section{Policy}

Dismissals under the "reasonableness" inquiry of the minimum contacts analysis, as well as these under the doctrine of forum non conveniens, can either help or harm international relations and principals of comity. Seemingly unfair assertions of jurisdiction over foreign defendants may sour U.S. foreign relations ${ }^{113}$ because such assertions invade another nation's sovereignty over its own citizens. ${ }^{114}$ Also, asserting jurisdiction over, and ultimately imposing liability on, foreign corporations may disrupt foreign commercial relations. ${ }^{115}$

Before exercising jurisdiction over foreign corporations, U.S. courts must be sensitive to baseline principles of comity. For example, dragooning too many foreign defendants into federal courts may threaten the recognition of U.S. judgments by foreign courts. ${ }^{16}$ Likewise, broad assertions over foreign nationals whose sovereigns maintain retaliatory jurisdiction statutes directly impact future litigation by U.S. defendants in those fora by increasing the

for securities."); accord S.E.C. v Banca Della Svizzera Italiana, 92 FRD 111, 117 (SD NY 1981) ("The strength of the United States' interest in enforcing its securities laws to ensure the integrity of its financial markets cannot seriously be doubted.").

112. See DeYoung, $707 \mathrm{~F}$ Supp at 139 ("[T]he interest of Canada in having controversies relating to one of its major corporations decided at home is substantial.").

113. See Howe, 946 F2d at 950 ("To insist that American courts hear cases where the balance of convenience and the interests of justice require that they be brought elsewhere will simply encourage an international forum-shopping that would increase the likelihood that decisions made in one country will cause (through lack of awareness or understanding) adverse effects in another, eroding uniformity or thwarting the aims of law and policy."); Asahi, 480 US at 115 ("The procedural and missing substantive interests of other nations in a state court's assertion of jurisdiction over an alien defendant will differ from case to case. In every case, however, those interests, as well as the Federal interest in Government's foreign relations policies, will be best served by a careful inquiry into the reasonableness of the assertion of jurisdiction in the particular case, and an unwillingness to find the serious burdens on an alien defendant outweighed by minimal interest on the part of the plaintiff or the forum state.").

114. In re Uranium Antitrust Litigation, 617 F2d 1248, 1253 (7th Cir 1980) (foreign government filed amici curiae briefs challenging assertion of federal jurisdiction over their citizens).

The interests of other nations "as well as the Federal interest in its foreign relations policy, will be best served by a careful inquiry into the reasonableness of the assertion of jurisdiction in the particular case . . . 'Great care and reserve should be exercised when extending our notions of personal jurisdiction into the international field." "Asahi, 480 US at 115, quoting First National City Bank, 379 US at 404 (Harlan dissenting).

115. Lauritzen $v$ Larsen, 345 US 571, 582 (1953).

116. For example, British industrial outcry over broad U.S. exercises of jurisdiction over British corporations has thwarted efforts in the past for the United States and Great Britain to agree on more liberal recognition of each others' judgments. P. M. North, The Draft U.K./US Judgments Convention: A British Viewpoint, 1 Nw J Intl L \& Bus 219, 233-8 (1979). 
chances of retaliatory jurisdiction. ${ }^{117}$ Broad assertions of jurisdiction over foreign defendants whose home countries maintain deferential jurisdictional118 attitudes could cause those countries to change those favorable attitudes. National courts retaining considerable discretion in exercising long-arm jurisdiction, especially those with rigid or unrestricted jurisdictional laws, should not be unduly provoked into broader assertions of jurisdiction over U.S. citizens.119 Considering the alternative forum's jurisdictional laws and other matters of policy, a U.S. court may be better served by allowing a foreign judiciary to resolve the litigation.

\section{Conclusion}

This article has attempted to outline key areas of analysis in obtaining personal jurisdiction over foreign corporate subsidiaries under the jurisdictional provisions of the Securities Exchange Act of 1934. By defining the character and nature of a particular parent-subsidiary relationship, and by understanding the various bases on which jurisdiction can rest, counsel can better predict whether a foreign subsidiary will be subject to federal jurisdiction in securities cases. Furthermore, the "reasonableness" analysis and the doctrine of forum non conveniens can be used in tandem to argue powerfully against the assertion of jurisdiction in a given case. Ultimately, this article is designed to assist counsel in preparing and defending motions to dismiss for lack of personal jurisdiction and forum non conveniens in international securities litigation involving subsidiary corporations.

117. For example, a domiciliary of Belgium can bring suit against a foreign defendant whose national courts would assert jurisdiction over a comparable action. Judicial Code arts 635,636 , and 638. Italy also has a similar retaliatory jurisdiction statute. CPC art 4(4).

118. For example, Japan generally gives deference to Aliens by limiting the assertion of jurisdiction to aliens living in Japan or causes of action that arose in Japan. CCP art 1-29. The Japanese have historically interpreted their procedural rules in favor of aliens. Yasuhiro Fujita, Procedural Faimess to Foreign Litigants as Stressed by Japanese Courts, 12 Intl Law 795 (1978).

119. English courts enjoy broad discretion in withholding such approval, considering burdens on defendants and/or doubts about the merits of the plaintiff's case. Cordova Land Co. $v$ Victor Bros., 1 WLR 793 (1966). Under England's statute-based long-arm jurisdictional authority, prior judicial approval must be obtained before process can be served outside the jurisdiction. RSC, (Eng), $0.11, r$ 1. In Germany, the exercise of personal jurisdiction over non-Germans is proper if they own property in Germany, regardless of the value or nature of the property. Personal jurisdiction can be exercised in any amount, even exceeding the value of the property located in Germany. ZPO art 23. Kurt H. Nadelmann, Jurisdictionally Improper Fora, XXth Century Comparative and Conflicts Law 321 , 329 (1961). French courts exercise seemingly unrestricted jurisdictional reach because their laws do not require any real interaction between the alien defendant and France. French courts can exercise jurisdiction over any case in which the plaintiff is a French citizen. C Civ art 15. 